\title{
PENGGUNAAN TEPUNG KULIT BUAH MARKISA YANG DIFERMENTASI DENGAN Phanerochaete chrysosporium TERHADAP KARKAS KELINCI REX JANTAN LEPAS SAPIH
}

\author{
The Utilization of Fermented (Passiflora edulis) by Phanerochaete chrysosporium on \\ Carcass of Weaning Male Rex Rabbit
}

\author{
Frinando S Pakpahan ${ }^{1}$, Ma'ruf Tafsin², dan Nevy Diana Hanafi ${ }^{2}$ \\ 1. Mahasiswa Program Studi Peternakan Fakultas Pertanian Universitas Sumatera Utara \\ 2. Staf Pengajar Program Studi Peternakan Fakultas Pertanian Universitas Sumatera Utara
}

\begin{abstract}
One of the potential alternative feed is fermented passion fruit pell by Phanerochaete chrysosporium. The study aims to determine the effect flour of passion fruit pell fermentation with Phanerochaete chrysosporium againts carcass of weaning male rex rabbit. This research was conducted at Rukun Farm Berastagi, from August to October 2015. This research used Completely Randomize Design (CDR) with 4 treatments and 5 replications. Each replications consists of 20 rex rabbit male weaning with initial body weight $918 \pm 75,18 \mathrm{~g}$. The treatments were level of fermented passiflora edulis by Phanerochaete chrysosporium on concentrate compose of $P_{0}(0 \%) ; P_{1}(10 \%) ; P_{2}(20 \%)$ and $P_{3}(30 \%)$. The variables were observed consist of body weight, carcass weight, percentage carcass, relative organ weight in and relative organ weight outside. The result showed that the treatment significant influenced $(P<0,05)$ on body weight, carcass weight, percentage carcass, relative digestive tract weight, relative skin weight. Conversely, had no significant effect $(P>0,05)$ on relative organ weight $(\mathrm{g} / \mathrm{kg} \mathrm{BW})$ heart, lungs, liver, kidney, head and feet. The conclusion of this research that the utilization of fermented passiflora edulis by Phanerochaete chrysosporium until level $30 \%$ of the concentrate can be increase body weight, carcass weight and percentage carcass of weaning male rex rabbit.
\end{abstract}

Keywords : Passion fruit peel, fermentation, Phanerochaete chrysosporium, Carcass, Rabbit

\begin{abstract}
ABSTRAK
Salah satu potensi bahan pakan alternatif adalah kulit buah markisa yang difermentasi dengan Phanerochaete chrysosporium. Penelitian ini bertujuan untuk melihat pengaruh pemberian tepung kulit buah markisa yang difermentasi dengan Phanerochaete chrysosporium terhadap karkas kelinci rex jantan lepas sapih. Penelitian dilaksanakan di Rukun Farm Berastagi, pada bulan Agustus-Oktober 2015. Rancangan yang digunakan adalah rancangan acak lengkap (RAL) dengan 4 perlakuan dan 5 ulangan. Setiap ulangan terdiri dari 20 ekor kelinci rex jantan lepas sapih dengan rataan bobot badan awal 918 $\pm 75,18$ g. Perlakuan dengan berbagai level kulit buah markisa fermentasi Phanerochaete chrysosporium dalam ransum terdiri dari $\mathrm{P}_{0}(0 \%) ; \mathrm{P}_{1}(10 \%)$; $\mathrm{P}_{2}(20 \%)$ dan $\mathrm{P}_{3}(30 \%)$. Parameter yang diteliti adalah bobot potong, bobot karkas, persentase karkas, bobot relatif organ dalam dan bobot relatif organ luar. Hasil penelitian menunjukkan bahwa perlakuan berpengaruh nyata $(\mathrm{P}<0,05)$ terhadap bobot potong, bobot karkas, persentase karkas, bobot relatif saluran pencernaan dan bobot relatif kulit. Sebaliknya, tidak berbeda nyata $(\mathrm{P}>0,05)$ pada bobot relatif jantung, paru-paru, hati, ginjal, kepala dan kaki. Kesimpulan dari penelitian ini adalah penggunaan tepung kulit buah markisa yang difermentasi denganPhanerochaete chrysosporium sampailevel 30\% dalam ransum dapat meningkatkan bobot potong, bobot karkas dan persentase karkas kelinci rex jantan.
\end{abstract}

Kata kunci : Kulit Buah Markisa, Fermentasi, Phanerochaete chrysosporium, Karkas, Kelinci 


\section{PENDAHULUAN}

Sumatera Utara merupakan salah satu daerah sentral produksi markisa (Passiflora edulis) di Indonesia. Menurut Tangdilintin (1994), produksi limbah kulit buah markisa sebanyak 2,5-4 ton per hari. Limbah industri perkebunan dan pengolahan buah markisa berupa kulit buah markisa masih mengandung nutrisi yang sangat potensial untuk digunakan sebagai pakan ternak kelinci pada daerah industri pengolahan buah markisa seperti di Berastagi.Umumnya kulit buah markisa belum dimanfaatkan secara optimal, sehingga berpotensi sebagai bahan pakan ternak karena kandungan gizinya cukup baik.

Kandungan nutrisi kulit buah markisa adalah protein kasar (PK) 12,37\%, lemak kasar (LK) 5,28\%, serat kasar (SK) 30,16\% dan abu 9,26\%. Kulit buah markisa kurang baik dijadikan bahan baku untuk pakan ternak karena kandungan serat kasarterutama lignin yang tinggi, sehingga perlu dilakukan fermentasi dengan menggunakan Phanerochaete chrysosporium.

Phanerochaete chrysosporium merupakan jenis jamur pelapuk putih yang dapat mendegradasi kandungan serat kasar terutama lignin dan selulosa.Melihat kemampuan Phanerochaete chrysosporium dalam menghasilkan enzim lignolitik dan selulotik, kapang ini mampu menurunkan kandungan lignin dengan meningkatkan pertumbuhan kapang dan aktivitas enzim lignolitik.

Ternak kelinci tidak dapat mencerna serat kasar dengan baik, fermentasi kulit buah markisadenganPhanerochaete chrysospriumdiharapkan dapat meningkatkan nilai nutrisi dan mengurangi kandungan serat kasarnya, sehingga lebih mudah dicerna kelinci untuk proses metabolisme tubuhnya.

Adapun tujuan dari penelitian ini adalah menguji pemberian tepung kulit buah markisa yang difermentasi dengan Phanerochaete chrysosporium terhadap bobot potong, bobot karkas, persentase karkas danbobot relatif komponen non karkas kelinci Rex jantan lepas sapih.

\section{BAHAN DAN METODE PENELITIAN}

\section{Lokasi dan Waktu Penelitian}

Penelitian dilaksanakan di Jl. Udara Gg. Rukun (Peternakan Kelinci Rukun Farm) Berastagi, Kabupaten Karo. Penelitian ini berlangsung selama 3 bulan dimulai dari 03 Agustus 2015 sampai dengan 13 Oktober 2015. 


\section{Bahan dan Alat Penelitian}

Bahan yang digunakan yaitu kelinci Rex jantan lepas sapih 20 ekor dengan rata-rata bobot badan $918 \pm 75,18 \mathrm{~g}$. Bahan pakan yang terdiri darikulit buah markisa, tepung jagung, dedak padi, bungkil kedelai, tepung ikan, top mix dan molases. Kulit Buah Markisa (KBM) difermentasi dengan jamur Phanerochaete chrysosporiumkemudian bahanpakandiolah menjadi pakan berbentuk pelet. Daun wortel sebagai hijauan, obat-obatan seperti Permentyhl 5\% sebagai obat kembung, Pyroxy sebagai antibiotik dan vitamin B-complex serta rodalon sebagai desinfektan.

Alat yang digunakan yaitu kandang individu sebanyak 20 petak, timbangan kapasitas $5 \mathrm{~kg}$, tempat pakan pada tiap kandang dengan total sebanyak 20 unit, mesin giling, mesin pencetak pelet, autoclave, oven, termometer, alat pembersih kandang, kantong plastik, pisau pemotong dan gunting bedah.

\section{Metode Penelitian}

Metode penelitian yang digunakan adalah rancangan acak lengkap (RAL) dengan 4 perlakuan dan 5 ulangan.Adapun perlakuan yang diteliti adalah sebagai berikut :

P0 : Ransum dengan penambahan 30\% KBM tanpa fermentasi dan 0\% KBM fermentasi Phanerochaete chrysosporium

P1 : Ransum dengan penambahan 20\% KBMtanpa fermentasi dan 10\% KBM fermentasi Phanerochaete chrysosporium

P2 : Ransum dengan penambahan 10\% KBMtanpa fermentasi dan 20\% KBM fermentasi Phanerochaete chrysosporium

P3 : Ransum dengan penambahan 0\% KBMtanpa fermentasi dan 30\% KBM fermentasi Phanerochaete chrysosporium

\section{Parameter Penelitian}

\section{a. Bobot Potong (g/ekor)}

Bobot potong adalah bobot kelinci yang diperoleh dengan cara penimbangan bobot akhir kelinci setelah dipuasakan selama 6-10 jam sebelum disembelih (Masanto dan Agus, 2010).

\section{b. Bobot Karkas (g/ekor)}

Bobot karkasdiperoleh dari hasil penimbangan dari daging bersama tulang kelinci hasil pemotongan setelah dipisah dari kepala, kaki, kulit, darah dan pengeluaran isi rongga perut (Rahman, 2014). 


\section{c. Bobot Komponen Non Karkas}

1. Bobot Relatif Organ dalam (g/kg BB)

Bobot relatif organ bagian dalamdiperoleh dari hasil penimbangan masing-masing komponen organ bagian dalam dibagi dengan bobot potong $(\mathrm{kg})$. Komponen organ bagian dalam yaitu jantung, hati, ginjal, paru-paru dan saluran pencernaan.

2. Bobot Relatif Organ luar $(\mathrm{g} / \mathrm{kg} \mathrm{BB})$

Bobot relatif organ bagian luar diperoleh dari hasil penimbangan masing-masing komponen organ bagian luar dibagi dengan bobot potong (kg). Komponen organ bagian luar yaitu kepala, kaki dan kulit segar.

\section{d. Persentase Bobot Karkas (\%)}

$$
\% \text { Bobot Karkas }=\frac{\text { Bobot Karkas }}{\text { Bobot Potong }} \times 100 \%
$$

(Santoso, 2010).

Tabel 1. Susunan Ransum Kelinci :

\begin{tabular}{clcccc}
\hline \multirow{2}{*}{ No } & \multirow{2}{*}{ Bahan } & $\mathrm{P}_{0}$ & $\mathrm{P}_{1}$ & $\mathrm{P}_{2}$ & $\mathrm{P}_{3}$ \\
\cline { 2 - 6 } 1. & KBM & 30 & 20 & 10 & 0 \\
2. & KBM Fermentasi & 0 & 10 & 20 & 30 \\
3. & Tepung Jagung & 30 & 30 & 30 & 30 \\
4. & Dedak Padi & 11 & 11 & 11 & 11 \\
5. & Bungkil Kedelai & 14 & 14 & 14 & 14 \\
6. & Tepung Ikan & 7 & 7 & 7 & 7 \\
8. & Top Mix & 2 & 2 & 2 & 2 \\
9. & Molases & 6 & 6 & 6 & 6 \\
\hline \multicolumn{7}{c}{ Total } & 100 & 100 & 100 & 100 \\
\hline 1. & PK (\%) & 15,93 & 16,94 & 17,94 & 19,27 \\
2. & EM (kkal/kg) & 2845,75 & 2849,75 & 2853,75 & 2857,75 \\
3. & SK (\%) & 15,42 & 14,96 & 14,50 & 14,04 \\
4. & LK $(\%)$ & 4,10 & 4,18 & 4,26 & 4,34 \\
\hline * Berdasarkan Perhitungan & \multicolumn{5}{c}{ Nutrisi* }
\end{tabular}




\section{HASIL DAN PEMBAHASAN}

\section{Bobot Potong}

Hasil analisis ragam menunjukkan bahwa penggunaan tepung kulit buah markisa fermentasi Phanerochaete chrysosporium dengan berbagai level dalam ransum memberikan pengaruh yang berbeda nyata $(\mathrm{P}<0,05)$ terhadap bobot potong kelinci rex jantan. Dari uji lanjut (Duncan's Multiple Range Test) yang dilakukan, menunjukkan bahwa bobot potong kelinci rex jantan mengalami peningkatan mulai dari perlakuan P1, P2 dan P3, sehingga terlihat bahwa ransum yang diberi kulit buah markisa fermentasi lebih baik bobot potongnya dibandingkan kulit buah markisa tanpa fermentasi.

Tabel 2. Hasil rataan bobot potong, bobot karkas dan persentase karkas kelinci rex jantan

\begin{tabular}{|c|c|c|c|}
\hline \multirow{2}{*}{ Perlakuan } & \multicolumn{3}{|c|}{ Parameter Penelitian } \\
\hline & Bobot Potong (g) & Bobot Karkas (g) & Persentase Karkas (\%) \\
\hline $\mathrm{P} 0$ & $1759,60^{\mathrm{b}} \pm 49,83$ & $908,40^{\mathrm{b}} \pm 18,84$ & $51,63^{\mathrm{b}} \pm 0,41$ \\
\hline $\mathrm{P} 1$ & $1843,00^{\mathrm{ab}} \pm 74,37$ & $954,40^{\mathrm{a}} \pm 34,14$ & $51,79^{b} \pm 0,57$ \\
\hline $\mathrm{P} 2$ & $1852,80^{\mathrm{a}} \pm 53,68$ & $960,40^{\mathrm{a}} \pm 32,28$ & $51,83^{\mathrm{b}} \pm 0,32$ \\
\hline P3 & $1875,40^{\mathrm{a}} \pm 69,09$ & $983,00^{\mathrm{a}} \pm 33,79$ & $52,42^{\mathrm{a}} \pm 0,36$ \\
\hline
\end{tabular}

Ket : Superskrip yang berbeda pada kolom yang sama menunjukkan perbedaan yang nyata $(\mathrm{P}<0,05)$

Kulit buah markisa (protein kasar 8,53\%) yang difermentasi selama 15 hari oleh Phanerochaete chrysosporium dapat meningkatkan kandungan protein kasar menjadi $18,56 \%$. Semakin lama waktu fermentasi, semakin banyak kapang yang dapat menguraikan substrat (kulit buah markisa). Miselium/hifa dan enzim yang dihasilkan juga akan semakin banyak sesuai dengan pertumbuhan kapang. Howard et al. (2003) menjelaskan bahwa kapang yang mempunyai pertumbuhan dan perkembangbiakan yang baik akan dapat merubah lebih banyak komponen penyusun media menjadi suatu massa sel, sehingga akan terbentuk protein yang berasal dari tubuh kapang itu sendiri dan dapat meningkatkan protein kasar dari bahan. Selama proses fermentasi mikroba akan mengeluarkan enzim dimana enzim tersebut adalah protein dan mikroba itu sendiri juga merupakan sumber protein. Peningkatan jumlah enzim dan populasi mikroba dalam proses fermentasi akan menyediakan protein kasar dalam kulit buah markisa, yang mana kandungan ini sangat dibutuhkan dalam metabolisme tubuh sehingga meningkatkan bobot potong kelinci rex jantan.

Meningkatnya kualitas nutrisi kulit buah markisa akan mempengaruhi kualitas ransum. Hasil penelitian menunjukkan perlakuan P3 memiliki bobot potong tertinggi, hal ini 
dipengaruhi oleh faktor kandungan nutrisi dalam ransum, dimana ransum memiliki kandungan protein kasar berkisar 15,93-19,27\%. Ransum yang memiliki kandungan tingkat protein yang tepat dan seimbang akan menghasilkan bobot potong yang optimal karena tingkat protein dalam ransum yang tepat akan mudah dicerna dan diserap dengan baik oleh tubuh ternak. Hasil bobot potong tertinggi pada penelitian ini terdapat pada perlakuan P3 dengan rataan bobot potong1875,40 g/ekor. Hasil penelitian ini lebih rendah dari penelitian Rohmatin (2010) yang menggunakan protein 18,2 \% (ransum komplit mengandung bungkil kelapa, rumput lapang, dan daun ubi jalar) dengan bobot potong sebesar 1797 g/ekor.

\section{Bobot Karkas}

Hasil analisis ragam menunjukkan bahwa penggunaan tepung kulit buah markisa yang difermentasi dengan Phanerochaete chrysosporium dengan berbagai level dalam ransum memberikan pengaruh yang berbeda nyata $(\mathrm{P}<0,05)$ terhadap bobot karkas kelinci rex jantan. Dari uji lanjut (Duncan's Multiple Range Test) yang dilakukan, menunjukkan bahwa bobot karkas kelinci rex jantan mengalami peningkatan mulai dari perlakuan P1, P2 dan P3, sehingga terlihat bahwa P3 memiliki bobot karkas tertinggi dari perlakuan lainnya, dengan pengertian ransum yang diberi kulit buah markisa fermentasi lebih baik bobot karkasnya dibandingkan kulit buah markisa tanpa fermentasi.

Kulit Buah Markisa yang difermentasi dengan Phanerochaete chrysosporium selama 15 hari memiliki kandungan protein kasar 18,56\%. Dalam waktu fermentasi tersebut miselium kapang akan semakin banyak, dimana kapang akan menguraikan kulit buah markisa terutama komponen serat kasar. Selama proses fermentasi mikroba akan mengeluarkan enzim dimana enzim tersebut adalah protein dan mikroba itu sendiri juga merupakan sumber protein sel tunggal (Howard et al., 2003). Peningkatan jumlah enzim dan populasi kapang akan meningkatkan kandungan protein kasar kulit buah markisa. Kandungan protein inilah yang dimanfaatkan ternak dalam proses metabolisme tubuh sehingga akan meningkatkan proporsi daging dan selanjutnya akan berpengaruh pada bobot karkas.Supriyadi (2013) menyatakan bahwa faktor yang mempengaruhi bobot karkas adalah umur, jenis dan pakan (lemak dan protein) yang digunakan. Kelinci yang digunakan dalam penelitian ini berjenis sama yaitu kelinci Rex dengan umur 2 bulan dan bobot potong sekitar 1674-1958 g/ekor. Kandungan lemak dan protein kasar dalam ransum perlakuan yaitu sekitar 4,1-4,3\% dan 15,9-19,2\%. Hal ini menunjukkan bahwa selisih kandungan protein kasar antara perlakuan P0 dengan P3 sebesar 3,3\%, dalam kisaran tersebut maka kandungan nutrisi ransum dapat mempengaruhi 
produksi bobot karkas. Keseimbangan kandungan protein dalam ransum sangat diperlukan untuk memperoleh produksi karkas yang optimal. Hasil penelitian ini sesuai dengan penelitian Rohmatin (2010) dengan menggunakan nilai protein pakan 17,4\% (dengan menggunakan bungkil inti sawit, rumput lapang dan daun lamtoro) dengan rataan bobot karkas sebesar $991 \mathrm{~g} / \mathrm{ekor}$.

\section{Persentase Karkas}

Hasil analisis ragam menunjukkan bahwa penggunaan tepung kulit buah markisa yang difermentasi dengan Phanerochaete chrysosporium memberikan pengaruh yang berbeda nyata $(\mathrm{P}<0,05)$ terhadap persentase karkas kelinci rex jantan. Dari uji lanjut (Duncan's Multiple Range Test) yang dilakukan, menunjukkan bahwa perlakuan P3 memiliki persentase karkas tertinggi dari perlakuan lainnya.

Data rataan persentase karkas (\%) terhadap bobot potong yang didapatkan dalam penelitian ini adalah berkisar 51,63\%-52,42\%. Hasil penelitian ini sesuai dengan laporan Masanto dan Agus (2010) yang menyatakan bahwa kelinci pedaging memiliki kriteria persentase karkas 50-60\% dengan bobot badan mencapai $2 \mathrm{~kg}$ pada umur 8 minggu. Persentase karkas dalam penelitian ini dipengaruhi oleh faktor kualitas nutrisi dalam ransum. Hasil penelitian menunjukkan P3 memiliki persentase karkas yang lebih tinggi dibandingkan P0, P1 dan P2. Hal ini disebabkan kandungan protein kasar dan serat kasar dalam ransum, dimana kandungan protein kasar dan serat kasar dipengaruhi oleh kulit buah markisa yang difermentasi selama 15 hari oleh Phanerochaete chrysosporium. Selama proses fermentasi, peningkatan jumlah enzim dan populasi kapang akan meningkatkan kandungan protein kasar dan mengurangi serat kasar kulit buah markisa yang selanjutnya akan mempengaruhi kualitas ransum dan persentase karkas.

\section{Bobot Relatif Organ Dalam}

Hasil analisis ragam pada penggunaan tepung kulit buah markisa fermentasi Phanerochaete chrysosporium dengan berbagai level dalam ransum memberikan pengaruh yang berbeda tidak nyata $(\mathrm{P}>0,05)$ terhadap bobot relatif paru-paru, jantung, hati dan ginjal kelinci rex jantan. Sedangkan pada bobot relatif organ pencernaan memberikan pengaruh yang berbeda nyata $(\mathrm{P}<0,05)$.

Hati dan ginjal berbeda tidak nyata karena bobot hati, ginjal, jantung dan paru-paru dipengaruhi oleh perkembangan yang sesuai dengan berat tubuh. Widiarto et al. (2009) menyatakan bahwa persentase bobot jeroan merah terdiri atas jantung, paru-paru, trakea dan 
paru-paru, ginjal, limpa dan hati yang memiliki perkembangan sesuai dengan berat tubuh dan pada saat dewasa tubuh akan mengalami penurunan.

Tabel 3. Hasil rataan bobot relatif organ dalam $(\mathrm{g} / \mathrm{kg} \mathrm{BB})$

\begin{tabular}{lrrrr}
\hline \multirow{2}{*}{\multicolumn{1}{c}{ Peubah }} & \multicolumn{4}{c}{ Perlakuan } \\
\cline { 2 - 5 } & \multicolumn{1}{c}{$\mathrm{P}_{0}$} & \multicolumn{1}{c}{$\mathrm{P}_{1}$} & \multicolumn{1}{c}{$\mathrm{P}_{2}$} & \multicolumn{1}{c}{$\mathrm{P}_{3}$} \\
\hline Jantung $^{\text {th }}$ & $3,07 \pm 0,27$ & $3,16 \pm 0,33$ & $3,25 \pm 0,62$ & $3,52 \pm 0,62$ \\
Paru-paru $^{\text {tn }}$ & $7,37 \pm 0,88$ & $7,47 \pm 0,69$ & $7,55 \pm 0,70$ & $7,78 \pm 0,37$ \\
Ginjal $^{\text {tn }}$ & $6,92 \pm 0,94$ & $7,36 \pm 0,71$ & $7,43 \pm 0,77$ & $7,45 \pm 0,73$ \\
Hati $^{\text {tn }}$ & $27,16 \pm 0,49$ & $27,26 \pm 0,75$ & $27,87 \pm 1,09$ & $28,14 \pm 0,69$ \\
Organ Pencernaan $_{\text {(Oesophagus- Anus) }}$ & $100,32 \pm 2,20^{\mathrm{a}}$ & $96,92 \pm 1,49^{\mathrm{b}}$ & $96,44 \pm 4,00^{\mathrm{b}}$ & $95,64 \pm 0,75^{\mathrm{b}}$ \\
\hline
\end{tabular}

Ket : Superskrip yang berbeda pada baris yang sama menunjukkan perbedaan yang nyata $(\mathrm{P}<0,05)$

tn : tidak berbeda nyata

Berdasarkan hasil uji lanjut (Duncan's Multiple Range Test) yang dilakukan, menunjukkan bahwa bobot relatif organ pencernaan kelinci rex jantan yang diberi perlakuan $\mathrm{P}_{0}$ menghasilkan bobot relatif organ pencernaan yang nyata $(\mathrm{P}<0,05)$ lebih tinggi daripada perlakuan $\mathrm{P}_{1}, \mathrm{P}_{2}$ dan $\mathrm{P}_{3}$. Hasil penelitian menunjukkan bobot relatif organ pencernaan kelinci rex jantan mengalami penurunan mulai dari perlakuan $\mathrm{P}_{1}, \mathrm{P}_{2}$ dan $\mathrm{P}_{3}$. Hal ini karena faktor kandungan nutrisi dalam ransum, dimana ransum $\mathrm{P}_{0}$ dan $\mathrm{P}_{3}$ memiliki kandungan serat kasar $15,42 \%$ dan $14,04 \%$ yang menyebabkan $\mathrm{P}_{0}$ memiliki bobot organ pencernaan yang lebih tinggi dari perlakuan lainnya. Rahman (2014) menyatakan bahwa organ yang berhubungan dengan digesti dan metabolisme menunjukkan pertambahan berat yang besar sesuai dengan status nutrisional dan fisiologis ternak. Apabila pemberian serat kasar tinggi akan meningkatkan isi perut dan menurunkan persentase karkas. Tingkat kandungan serat kasar ini dipengaruhi oleh bahan pakan kulit buah markisa (Serat Kasar 39,56\%), dimana setelah difermentasi dengan Phanerochaete chrysosporium dapat menurunkan kandungan serat kasar kulit buah markisa yaitu $34,96 \%$.

\section{Bobot Relatif Organ Luar}

Hasil analisis ragam menunjukkan bahwa penggunaan tepung kulit buah markisa yang difermentasi dengan Phanerochaete chrysosporium dengan berbagai level dalam ransum memberikan pengaruh yang berbeda tidak nyata $(\mathrm{P}>0,05)$ terhadap bobot relatif kepala dan kaki kelinci rex jantan, sedangkan pada bobot relatif kulit menunjukkan hasil yang berbeda nyata $(\mathrm{P}<0,05)$. 
Tabel 4. Hasil rataan bobot relatif organ luar $(\mathrm{g} / \mathrm{kg} \mathrm{BB})$

\begin{tabular}{lrrrr}
\hline \multirow{2}{*}{ Peubah } & \multicolumn{4}{c}{ Perlakuan } \\
\cline { 2 - 5 } & \multicolumn{1}{c}{$\mathrm{P}_{0}$} & \multicolumn{1}{c}{$\mathrm{P}_{1}$} & \multicolumn{1}{c}{$\mathrm{P}_{2}$} & \multicolumn{1}{c}{$\mathrm{P}_{3}$} \\
\hline Kepala $^{\text {tn }}$ & $61,93 \pm 0,94$ & $62,01 \pm 1,66$ & $62,09 \pm 0,90$ & $62,20 \pm 0,82$ \\
Kaki $^{\text {tn }}$ & $29,10 \pm 0,28$ & $29,20 \pm 0,23$ & $29,48 \pm 0,37$ & $29,65 \pm 0,08$ \\
Kulit $^{l}$ Ket : Superskrip yang berbeda pada baris yang sama menunjukkan perbedaan yang nyata $(\mathrm{P}<0,05)$ \\
tn : tidak berbeda nyata
\end{tabular}

Perlakuan tidak berpengaruh nyata terhadap bobot relatif kepala dan kaki, hal ini disebabkan pertumbuhan bobot kepala dan kaki tidak dipengaruhi oleh nutrisi. Janatum (2007) menyatakan bahwa pertumbuhan kepala dan kaki sangat bervariasi dipengaruhi oleh umur, jenis kelamin dan lingkungan.

Berdasarkan hasil uji lanjut (Duncan's Multiple Range Test) yang dilakukan, menunjukkan bahwa perlakuan $\mathrm{P}_{3}$ memiliki bobot relatif kulit segar tertinggi dari perlakuan lainnya. Hal ini disebabkan perkembangan kulit dipengaruhi oleh faktor kandungan nutrisi dalam ransum, dimana ransum memiliki kandungan protein kasar berkisar 15,93-19,27\% . Perbedaan kandungan protein ini dipengaruhi oleh kulit buah markisa yang difermentasi dengan Phanerochaete chrysosporium sehingga meningkatkan kadar protein kasar dari $8,53 \%$ menjadi $18,56 \%$.

\section{KESIMPULAN}

Penggunaan tepung kulit buah markisa yang difermentasi dengan Phanerochaete chrysosporium lebih baik dibandingkan tanpa fermentasi, dimana penggunaan tepung kulit buah markisa fermentasi sampai level 30\% dapat meningkatkan bobot potong, bobot karkas dan persentase karkas kelinci rex jantan.

\section{DAFTAR PUSTAKA}

Howard, R. L., E. Abotsi, E. L. J van Rensburg and S. Howard. 2003. Lignocellulose biotechnology: issues of bioconversion and enzyme production. African J. Biotechnol.

Janatum. 2007. Pengaruh Pemberian Ransum Hijauan Dan Konsentrat yang Berbeda Terhadap Bobot Potong, Persentase Karkas dan Non Karkas Kelinci Lokal Jantan. Laporan Penelitian Fakultas Pertanian UNS, Surakarta.

Masanto, R dan Agus, A., 2010. Beternak Kelinci Potong. Penebar Swadaya. Jakarta.

Rahman, L., 2014. Pengaruh Jenis Kelamin Terhadap Persentase Beberapa Bagian NonKarkas (Offal) Kambing Kacang yang Dipelihara Secara Intensif [skripsi]. Fakultas Peternakan, Universitas Hasanuddin. 
Rohman, R. C. 2010. Persentase karkas dan organ dalam kelinci jantan lokal yang diberi ransum komplit mengandung bungkil inti sawit dengan kombinasi hijauan berbeda. [Skripsi]. Fakultas Peternakan. IPB. Bogor.

Santoso, U dan Sutarno., 2010. Bobot Potong dan Karkas Kelinci New Zealand White Jantan setelah Pemberian Ransum Kacang Koro (Mucuna pruriens). Bioteknologi. 7(1):1926.

Supriyadi, Minarti. S dan N. Cholis. 2013. Karasteristik Karkas Kelinci Peranakan New Zealand White Yang diberi Pakan Limbah Kubis (Brassica oleracea) Tercemar Pestisida. Universitas Brawijaya, Malang.

Tangdilintin, F.K., M. Rusdy, B.R.R. Mahi, Budiman, dan S. Rasyid. 1994. Pemanfaatan kulit buah markisa (Passiflora edulis Sims) sebagai pakan pengganti hijauan untuk ruminansia kecil. Ujung Pandang: OPF, Universitas Hasanuddin.

Widiarto, W., Widiarti, R., Budisatria IGS. 2009. Pengaruh berat potong dan harga pembelian domba dan kambing betina terhadap gross margin jagal di rumah potong hewan Mentik, Kresen, Bantul. Buletin peternakan. 33(2) : 119-128. 